\title{
Bangladesh Trade with India: Trends and Patterns
}

\author{
By Anisul M. Islam*
}

Bangladesh has a large and persistent trade deficit with its neighboring country India over the years. This paper explored the trends and patterns of trade between these two countries using both aggregated and disaggregated data. More specifically, it examined the relative position of the two countries in global trade, explores the overall trend in exports to and imports from India, and the trend in trade balance using aggregate level data. Further, utilizing some disaggregated data, analysis is conducted regarding the commodity composition of Bangladesh exports to and imports from India by major product categories. Additionally, the paper estimates revealed comparative advantage (RCA) to reflect inter-industry trade based on comparative advantage by HS-2 digit commodity groups. The paper finds that India has a much stronger position in the global trade vis-à-vis Bangladesh and that India strongly dominates Bangladesh in bilateral trade, resulting in a very large and persistent trade deficit with India. At a disaggregated level, the paper finds that Bangladesh has comparative advantage in some products whereas India has comparative advantage relatively in more product categories.

Keywords: Exports, Imports, Revealed comparative advantage, Trade balance

\section{Introduction}

Bangladesh is a small emerging developing economy in South Asia whereas India is a large and dominant country in the South Asian region in terms of population, land area, other natural resource endowments, education and technology, and size of the economy compared to Bangladesh and other of its neighboring countries. India is also the second largest country in the world after China in terms of population size. In spite of being the second largest country in the world in terms of population, India still has much less population density (0.36 times) than Bangladesh and India has about twice (1.83 times) the level of standard of living measured by the magnitude of per capital GDP in international PPP\$ (author calculations based on world Bank 2018 data). Based on some other indicators, India and Bangladesh have strong similarity such as in terms of population growth rate (1 times), real GDP in PPP\$ growth rate (only 1.15 times), and the CPI based inflation rate (0.95 times) (author calculations based on world Bank 2018 data).

This paper examined the relative position of the two countries in global trade, explores the overall trend in exports to and imports from India, and the trend in trade balance using aggregate level data. Further, utilizing some disaggregated data, analysis is conducted regarding the commodity composition of Bangladesh exports to and imports from India by major product categories. Additionally, the

"Professor, University of Houston-Downtown, USA. 
paper estimates revealed comparative advantage (RCA) to reflect inter-industry trade based on comparative advantage. The paper uses data collected from various country level and international data sources. Both aggregate level and disaggregated level data were utilized in the study. The paper is of critical importance to political leaders and policy makers in both countries, including researchers, think tanks, academics, and various international organizations.

\section{Literature Review}

A brief review of literature is conducted and presented in this section. Rather and Gupta (2014) discusses the role and significance of Bangladesh-India cooperation to improve cross-border trade and investment between the two countries and emphasized that increased Indian investments in the Bangladesh economy could increase integration, generate employment and help reduce the large trade deficits of Bangladesh with India. The paper did not undertake any rigorous empirical analysis of the trade patterns between the two countries. In a different study, Islam (2011) examined the Bangladesh-India trade trends for a limited number of years and made some efforts to analyze the trade patterns between the two countries from 2005 to 2009 fiscal years. Along with the rising trade deficit problem facing Bangladesh with India, the paper also examined a number of trade barrier issues limiting trade between these two countries, particularly those that act to limit Bangladesh exports to India. The paper then focuses more on the trade potentials for Bangladesh with the North-Eastern parts of India where Bangladesh might have some comparative advantage in exporting certain products to these remote regions of India. He further argues that such trade would be highly complementary to both nations and have the potential to bring closer integration of Bangladesh with these rather isolated remote regions from the mainland India, particular the four regions of Assam, Tripura, Meghalaya and Mizoram, all bordering Bangladesh in the North-Eastern part of India located between Bangladesh and Myanmar.

Basher (2013) examines the UNCTAD data just for two years, 2001 and 2011, to analyze overall trade along with trade by some major commodity groups and finds that Bangladesh exports to India was dominated by primary products and its imports from India was also dominated by similar primary products instead of manufacturing products. The author examined several trade related indices such as revealed comparative advantage, bilateral trade intensity, trade specialization index, trade complimentary index and intra-industry trade index for those two years and found that Bangladesh and India trade is more competitive rather than complementary in nature. While this study did compute a number of trade related indices, a few of the measurement formulas were either written in a confusing manner and/or could even be inaccurate, rendering estimates and conclusion based on those estimates to be questionable. Additional studies that discussed various aspects of the trade and other economic relations between these two neighboring countries include studies by Ahmed (2006), Bammi (2010), Dutta (2010), and 
Mukherjee (2015). These studies also discussed the potentials for improving trade relations between the two countries from different perspectives.

Some of the existing empirical studies have shown that there exists a rather large and growing volume of informal (unofficial and underground) trade between the two countries. Kashyap (2014) reported that the informal exports from India to Bangladesh were about USD 4 billion, which is of about similar magnitude of the volume of formal trade. Such informal trade occurs through various border areas without official channel (smuggling) and some event through official channels but through such corrupt practices (such as under invoicing of imports with official knowledge but occurs through bribery). Additional studies that focused on this type of trade include Bakht (1994), Chaudhary (1995), IBCCI (2016), Pursell (2007), Pohit and Taneja (2000, 2003), Taneja (2001), World Bank (2015), among others. Most of these studies found existence of large volume of informal trade beyond the officially recorded trade. Additionally, Taneja (2001) found that Bangladesh has large trade deficit even in the informal trade sector beyond the rising trade deficit of the country in the official (formal) trade sector. Pursell (2007) also examined Bangladesh-India trade focusing on illegal trade between the two countries, especially in the context of Sugar industry trade. Using data from 1994 to 2005 for this industry, he used simulations to examine the implication of any possible free trade agreement on sugar trade between these two countries and came out with some policy recommendations. IBCCI (2016) mentions that the size of the informal trade could be as large as the formal trade and the direction of this trade being mostly dominated by trade flowing from India to Bangladesh, but not the other way around. As such, it can be argued that Bangladesh may have sizeable trade deficit with India in the area of informal trade as well.

Using product-specific disaggregated data, Basu and Datta (2007a) studied Bangladesh-India trade deficits and tried to find the causes of persistent deficits facing Bangladesh in its trade with India. In this effort, they estimated revealed comparative advantage (RCA) and cosine measures to examine trade similarity and trade complementarity between the two countries and found that Bangladesh and India trades in very similar products and has little trade complementarity. Using data for 1990 to 1998, they estimated RCA values at three-digit SITC classification level indicated that both India and Bangladesh has comparative advantage in unskilled labor-intensive goods and hence their exports become competitive rather than complementary in the global markets, not a surprising result due to the fact that both countries are low-wage labor-abundant countries. However, they also found that India has much higher RCA values than Bangladesh in many more product categories while Bangladesh has RCA values greater than India in only a small number of product categories, which poses Bangladesh in a greater disadvantage in its exports to India compared to the other way trade.

Going beyond the RCA measures, Basu and Datta (2007a) estimated the Cosine measure of export-export similarity and export-import complementarities between the two countries. These estimates also clearly showed much stronger advantages for India against Bangladesh in their mutual trade prospects in each other's markets. Another paper that used product-specific disaggregated data was 
by Alam, Uddin, Alam and Malakar (2009). They examined comparative advantage of Bangladesh vis-à-vis India and found that India has advantage in a variety of product categories whereas Bangladesh has such advantage in a limited number of product categories. Another study that used disaggregated data to examine composition and patterns of trade include Khan, Islam, Ashiqun, and Paul (2010) and found stronger advantage for India against Bangladesh.

Given that the two countries are close neighbors and given their strong political and diplomatic ties, the prospects for bilateral free trade agreements between Bangladesh and India were examined and their implications for both countries analyzed by several studies (Bhardwaj 2014, Bhuyan 2006, IBCCI 2016, Pursell and Sattar 2006, Razzaque and Basnett 2014, World Bank 2006, among others). These studies also examined the implications of a free trade agreement on the two countries trade and their respective trade balance positions.

Some other studies exist related to Bangladesh-India trade. However, most of these studies focus on the impact of exchange rate on trade imbalance between these two countries and found that Bangladesh has a large trade deficit with India and the volume of that deficit has been increasing over time (Akhtar and Salim 1999, Basu and Datta 2007a, Basu and Datta 2007b, Islam et al. 2013, Rahman 2005, among others). Basu and Datta (2007b) focused on and estimated bilateral overall trade deficits of Bangladesh with India and used aggregated annual timeseries data from 1974 to 2001 and co-integration analysis to estimate the export and import functions along with a trade balance function to examine the effects of misaligned exchange rate of Bangladeshi Taka against Indian Rupees in explaining the persistent trade deficits. In doing so, the authors tried to draw some parallel from Indonesian experience and suggested that Bangladeshi policy makers may want to draw some lessons from that country's experience in devising its own exchange rate policy. However, most of these studies are quite dated and utilizes time series data with small sample sizes, resulting in biased and unreliable parameter estimates. Further, some others do not utilize sophisticated statistical and econometric methodologies and techniques. Since these studies are not directly relevant for the purpose of this paper, further critical elaboration on these studies was not provided here.

\section{Methodology: Measurement of Trade Indicators and Data Sources}

We have utilized a number of trade related measurements and indicators in this study. The trade related measurements used in this paper are listed below with their respective formula with equation numbers on the L.H.S. are given as follows:

\section{Measurement of Trade Indicators}

Generally, the degree of trade globalization is measured by country exports, country imports or country overall trade (exports plus imports), each as \% of country GDP. However, following the WTO, this paper uses the following 
measure of the degree of trade globalization based on average of exports and imports as given in equation (1) below:

1. Degree of Country Trade Globalization (or Integration) $=$ Average Trade as $\%$ of GDP $=\{($ Country Exports + Country Imports $) / 2\} * 100 /$ GDP

The paper proposes to measure the relative significance of a country's trade in relation to global trade and uses separate measures for goods (merchandise) exports, commercial service exports, goods imports, and commercial service imports given by the following four equations (2) through (5) given below:

2. Country Goods Exports as \% of World Goods Exports $=($ Country Goods Exports*100)/World Goods Exports

3. Country Goods Imports as $\%$ of World Goods Imports $=($ Country Goods Imports*100)/World Goods Imports

4. Country Service Exports as \% of World Service Exports $=($ Country Service Exports*100)/World Service Exports

5. Country Service Imports as $\%$ of World Service Imports $=($ Country Service Imports*100)/World Service Imports

Going beyond a country's position in the global context, we will use some trade measures to indicate the bilateral trade between the two countries under study, Bangladesh and India. Several measures are proposed here which are related to bilateral aggregate trade given by the following four equations (6) through (9) given below:

6. Country Overall or Aggregate Trade $(\mathrm{T})=($ Country Exports + Country Imports $)=(\mathrm{X}+\mathrm{M})$

7. Country Exports as $\%$ of Country Total Trade $(\mathrm{T})=($ Country Exports $(\mathrm{X})$ *100)/Total Trade (T)

8. Country Overall Trade Balance $(\mathrm{TB})=($ Country Exports - Country Imports $)=(\mathrm{X}-\mathrm{M})$

Annual average growth rate of aggregate trade variable $(\mathrm{T})$ between the beginning and the ending year in the sample time-series data:

9. Annual Average Growth Rate of $\mathrm{T}=\left[\left\{(\mathrm{Tt}-\mathrm{Tt}-\mathrm{k})^{*} 100 / \mathrm{Tt}-\mathrm{k}\right\} /(\mathrm{k}-1)\right]$, where $\mathrm{k}$ is the number of year in the sample 
For measuring Bangladesh's country specific export and import shares, the following equations were used to measure such country-specific market shares given in equations (10) and (11) below:

10. Bangladesh Country-specific export shares $=$ (Bangladesh exports to country $\mathrm{j} * 100)$ / Bangladesh total exports to the world

11. Bangladesh Country-specific import shares $=($ Bangladesh imports from country $\mathrm{j} * 100$ ) / Bangladesh total imports from the world

For product-specific disaggregated data analysis for trade and trade balance, we propose several measures and indicators given by the following equations (10) through (12) below:

12. Share of Top Export of Product $i$ to India as \% of Total Bangladesh Exports to India $=(X i$ to India*100/X to India, $\quad$ where $\mathrm{i}=1,2, . ., 9$ top export products.

13. Share of Top Imports Product i from India as \% of Total Bangladesh Imports from India $=($ Mi from India $* 100 / M$ from India, $\quad$ where $\mathrm{i}=1$, $2, . ., 10$ top import products.

14. Total Trade with India in Product $\mathrm{i}(\mathrm{Ti})=(\mathrm{Xi}+\mathrm{Mi})$, where $\mathrm{i}=1,2, \ldots, \mathrm{n}$ product categories.

15. Trade Balance with India for Product $\mathrm{i}(\mathrm{TBi})=(\mathrm{Xi}-\mathrm{Mi})$, where $\mathrm{i}=1,2, . .$, $\mathrm{n}$ product categories.

Trade in different product categories can be classifies as inter-industry trade versus intra-industry trade. The former is the traditional trade which happens between two different product categories (a country exporting one product and importing a different product) based on comparative advantage (or disadvantage). The latter is the non-traditional intra-industry trade (a country exporting and importing within the same product category), which is based on product differentiation and economies of scale (Grubel-Lloyd 1975). This paper did not pursue the latter category of trade; rather it focuses on the former comparative advantage based inter-industry trade as elaborated further below.

The former type of trade and the issue of specialization based on comparative advantage are discussed extensively in the international trade literature. However, measuring comparative advantage at the product level is not that easy as such measures would requires a lot of data at the industry or product level such as product-specific export and import data as well as product-specific input productivity or input cost data. However, Belassa (1965) proposed a simpler measure which uses ex post trade data alone that would reveal comparative advantage or disadvantage in a given product i. A variant of this approach can be calculated by a formula as given in equation (16) as follows: 
16. Revealed Comparative Advantage for product i $(\mathrm{RCAi})=\{(\mathrm{Xi}-$ $\mathrm{Mi}) /(\mathrm{Xi}+\mathrm{Mi})\}$,

where $\mathrm{i}=1,2, . ., \mathrm{n}$ product categories.

A positive value of RCAi index would indicate revealed comparative advantage in that product for that country and a negative value would indicate revealed comparative disadvantage.

\section{Data Sources}

To measure the above mentioned trade related indicators, data were collected from various country specific national sources (both Bangladesh and India) and international sources which are publicly available. The national sources include Dhaka Chamber of Commerce and Industry (DCCI 2016), and India-Bangladesh Chamber of Commerce and Industry (IBCCI 2016). The international data sources include the WTO (2018), The World Bank (2018), Globaledge (2018) data from Michigan State University, among others. Both time-series data from 2009-2016 and cross-section data by major product categories for 2015 were collected and analyzed in the paper.

\section{Empirical Findings}

The empirical results are presented in this section. This section is subdivided into several sub-sections, each with its own sub-headings. Each country's trade performance in the context of global trade is given by equations (1), (2), (3), (4) and (5). The calculated values of these indicators are presented in Table 1 below.

\section{Bangladesh and India Trade Position in the Global Context: Performance Comparison}

This sub-section focuses on the comparative trade performance of Bangladesh and India in the context of global trade. The trade-GDP ratio (\%) is generally measured as total trade (Exports + Imports) as \% of country GDP to indicate a country's degree of trade openness and trade integration with the world. However, following the WTO's country trade profile reporting, the average of a country's exports to the word and imports from the world as \% of country GDP is used to measure trade openness and integration. Using this average-based measure as given in equation (1) above, the relative performance of Bangladesh is not too different than that of India as both countries' percentages are in the $22-24 \%$ range as reported in Table 1 with India having a slightly higher percentage value. Thus it can be argued that the degree of trade openness and integration of both countries with the rest of the world are very similar. 
Table 1. Bangladesh and India Global Trade Performance Comparison: 2015

\begin{tabular}{|l|c|c|c|}
\hline $\begin{array}{l}\text { Trade Performance Indicators in the } \\
\text { Global Context }\end{array}$ & India & Bangladesh & $\begin{array}{c}\text { India-Bangladesh } \\
\text { Comparison }\end{array}$ \\
\hline $\begin{array}{l}\text { Average Trade as (\%) of country } \\
\text { GDP }\end{array}$ & 24.8 & 22.4 & Similar \\
\hline $\begin{array}{l}\text { Goods Exports as \% of World Goods } \\
\text { Exports }\end{array}$ & 1.62 & 0.20 & India stronger \\
\hline Goods Exports World Rank & 19 & 60 & India stronger \\
\hline $\begin{array}{l}\text { Goods Imports \% of World Goods } \\
\text { Imports }\end{array}$ & 2.34 & 0.24 & India stronger \\
\hline Goods Imports World Rank & 13 & 54 & India Stronger \\
\hline $\begin{array}{l}\text { Service Exports as \% of World } \\
\text { Service Exports }\end{array}$ & 3.27 & 0.04 & India stronger \\
\hline Service Exports World Rank & 8 & 109 & India stronger \\
\hline $\begin{array}{l}\text { Service Imports as \% of World } \\
\text { Service Imports }\end{array}$ & 2.65 & 0.19 & India stronger \\
\hline Service Imports World Rank & 10 & 63 & India stronger \\
\hline
\end{tabular}

Sources: WTO (2016) www.WTO.org and author compilation.

However, if we estimate some other indicators separately for goods (merchandise) and commercial services using indicators given in equations (2), (3), (4), and (5), India has a much stronger trade position and performance in the global stage than Bangladesh in terms of all these indicators as shown in Table 1. Focusing on merchandise trade, India's share of world goods exports is $1.62 \%$ compared to Bangladesh's share of only $0.20 \%$ and with India's rank in the world being 19 compared to Bangladesh's rank at 60. In terms of commercial service exports, India's global share is even better at $3.27 \%$ of world commercial service exports compared to Bangladesh's share of only $0.04 \%$ and with India's world ranking of 8 (among top 10 in the world) compared to Bangladesh's world ranking of 109. Thus, in terms of export performance, India strongly outperforms Bangladesh in the global stage in both goods exports and commercial service exports in recent years (2015).

A similar picture arises in terms of the relative performance of imports as reported in Table 1. India's share of world goods imports is $2.34 \%$ compared to Bangladesh's share of only $0.24 \%$ and with India's rank in the world being 13 compared to Bangladesh's rank at 54. In terms of commercial service imports, India's global share is even better at $2.65 \%$ of world commercial service exports compared to Bangladesh's share of only $0.19 \%$ and with India's world ranking of 10 (among top 10 in the world) compared to Bangladesh's world ranking of 63. Thus, in terms of import performance, India again strongly outperforms Bangladesh in the global stage in both goods imports and commercial service imports. 
Bangladesh's Top Export and Import Partners in the World and Global Market Shares

This sub-section focuses on the top export partners and top import partners of Bangladesh and the respective market shares as reported in Table 2 and Table 3 below. The country-specific market shares are calculated based on equations (10) and (11) given earlier. Table 2 reports information about Bangladesh's top ten export partners with respective market (trade) shares for each of the countries. In 2015-16, the total exports from Bangladesh to the rest of the world was 41,222 million USD, of which the top ten countries constituted about $75 \%$ of the country's exports. Of the top ten, the U.S. was the largest market, taking in about $21 \%$ of total exports from Bangladesh followed by Germany with $15.56 \%$ and then the U.K. with $9.49 \%$. Thus, the U.S., Germany and the U.K. are the top three export markets for Bangladesh. It is significant to note here that India does not come within the top export partners of Bangladesh in spite of being the closest and a large and powerful neighboring country.

Table 2. Bangladesh's Top 10 Export Partners and Market Share (\%): 2015-16

\begin{tabular}{|l|c|c|}
\hline \multicolumn{1}{|c|}{ Partner Country } & Exports (million US\$) & $\begin{array}{c}\text { Market Share } \\
\text { (\% of Total Exports) }\end{array}$ \\
\hline United States & 5,107 & 21.01 \\
\hline Germany & 3,782 & 15.56 \\
\hline United Kingdom & 2,306 & 9.49 \\
\hline France & 1,560 & 6.42 \\
\hline Spain & 1,073 & 4.41 \\
\hline Canada & 1,024 & 4.21 \\
\hline Italy & 990 & 4.07 \\
\hline Netherlands & 836 & 3.44 \\
\hline Belgium & 794 & 3.27 \\
\hline Turkey & 655 & 2.7 \\
\hline Total Top Ten & $\mathbf{1 8 , 1 2 9}$ & $\mathbf{7 4 . 5 4}$ \\
\hline Total-Other Countries & 6,184 & 25.44 \\
\hline Total Exports & $\mathbf{2 4 , 3 1 3}$ & $\mathbf{1 0 0 . 0 0}$ \\
\hline
\end{tabular}

Sources: The WTO (2016), the World Bank (2016) and author calculations.

Table 3 provides estimates about Bangladesh's top ten import partners with respective market shares attributable to these countries. In 2015-16, the total imports of Bangladesh from the rest of the world were 41,222 million USD, of which the top ten countries accounted for about $69.31 \%$ of total imports with the remaining $31 \%$ from many other countries in the rest of the world. Of the top ten import partners, Thailand topped the list with $22.78 \%$ of total imports followed by India as the second largest import source with $11.23 \%$ of all imports, and China capturing the third position with about $8.76 \%$ of imports coming to Bangladesh. It seems clear that Bangladesh serves as a significant market for India's exports but India does not take in any significant amount of exports from Bangladesh. The trade relationship between India and Bangladesh thus seem quite asymmetrical 
with India having the stronger and more dominant position vis-a-vis its trade with Bangladesh.

Table 3. Bangladesh's Top 10 Import Partners and Market Share (\%): 2015-16

\begin{tabular}{|c|c|c|}
\hline Partner Country & Imports (million US\$) & $\begin{array}{c}\text { Market Share } \\
\text { \% of Total Imports) }\end{array}$ \\
\hline Thailand & 9,389 & 22.78 \\
\hline India & 4,631 & 11.23 \\
\hline China & 3,610 & 8.76 \\
\hline Indonesia & 2,462 & 5.97 \\
\hline Singapore & 2,127 & 5.16 \\
\hline Malaysia & 1,867 & 4.53 \\
\hline Brazil & 1,302 & 3.16 \\
\hline United States & 1,250 & 3.03 \\
\hline Japan & 970 & 2.35 \\
\hline Pakistan & 963 & 2.34 \\
\hline Total-Top Ten & $\mathbf{2 8 , 5 7 2}$ & $\mathbf{6 9 . 3 1}$ \\
\hline Other Countries & 12,650 & 30.69 \\
\hline Total Imports & $\mathbf{4 1 , 2 2 2}$ & $\mathbf{1 0 0 . 0 0}$ \\
\hline
\end{tabular}

Sources: The WTO (2016), the World Bank (2016) and author calculations.

\section{Bangladesh-India Trade: Analysis by Bilateral Aggregate Trade}

In this section, Bangladesh-India bilateral trade is analyzed on the basis of overall or aggregate trade. In particular, we will analyze growth and trend in exports, imports, total trade (exports plus imports) and their growth rate, exports as $\%$ of total trade, trade balance and its growth, among others. The analysis is carried out over recent years over the period of 2009-10 to 2015-16. The calculations are reported in Table 4 utilizing formulas given by equations (6) through (9) presented earlier.

In continuation of the asymmetrical trading relationship between the two countries and India's dominant position as discussed in the previous section, that situation is further reflected and reinforced in the inter-temporal trend in Bangladesh's exports to and imports from India along with the trend in exports $(\mathrm{X})$, imports $(\mathrm{M})$ and total trade $(\mathrm{T})$ (equation (6)), exports as \% of total trade (equation (7)), trade balance (TB) with India (equation (8)) and average annual trade growth (equation (9)). Table 4 reports the relevant time trend of these variables from 2009-10 to 2015-16 to provide evidences in these bilateral aggregate trade indicators. Columns 2, 3 and 4 of this table gives annual data of Bangladesh's exports to India, imports from India and total trade (exports plus imports) with India, and column 5 reports exports as \% of total trade.

Data reported in Table 4, columns 2, 3, and 4 show further that the total exports to India, imports from India and the total trade between them has been increasing steadily over time from 2009 to 2016. In terms of annual average growth rate over the sample period, the exports from the country has been growing at a slightly higher annual average rate of $37.73 \%$ compared to the annual average import growth rate of $28.38 \%$ with the total trade growing at an annual average 
rate of $29.19 \%$ as shown in the last row of Table 4 . The above result of exports growing faster than imports in recent years could be considered as a good and hopeful sign from the perspective of Bangladesh for possible reduction in the prevailing large deficits with India with the passage of time as discussed further below.

However, the estimates reported in column 5 of Table 4 related to Bangladesh exports to India as \% of Bangladesh total trade with India represents a rather poor export performance of Bangladesh with its trade with India. Bangladesh exports constitute only a small percentage, varying around just $10 \%$ of total trade with India as shown on column 5. This clearly indicates a disturbing picture from Bangladesh perspective in that Bangladesh trade with India is highly dominated by Bangladesh's imports from India (alternatively India's exports to Bangladesh dominates Bangladesh-India trade) to the tune of about $89 \%$ of total trade between them.

This asymmetric trading relation has resulted in a large and persistent trade deficit for Bangladesh as reported in col. 6 of Table 4 for 2015-16 in its formal trade. The last column of this table shows that Bangladesh has had a trade deficit over each year during this period and that the magnitude of the deficit seems to be quite large and persistent with no sign of any significant reduction. For example, in 2015-16, the total trade deficit was about 4,763.28 million USD compared to the deficit of 2,897.48 million in 2009-10. Hence the deficits are large and persistent indeed from the perspective of Bangladesh. In addition, over the seven year period from 2009-10 to 2015-16, the deficit has grown by $164.39 \%$ which translates into an annual average growth rate of $27.40 \%$ in the growth of deficits.

Table 4. Bangladesh-India Trade, Trade Balance and Trade Growth: 2009 -2016

\begin{tabular}{|c|c|c|c|c|c|}
\hline Year & $\begin{array}{c}\text { Exports } \\
\text { (X) } \\
\text { (m. US\$) }\end{array}$ & $\begin{array}{c}\text { Imports (M) } \\
(\mathrm{m} . \text { US\$) }\end{array}$ & $\begin{array}{c}\text { Trade }= \\
(\mathbf{X}+\mathbf{M}) \\
(\mathbf{m} . \text { US\$) }\end{array}$ & $\begin{array}{c}\text { Exports as } \\
\% \text { of } \\
\text { Trade }\end{array}$ & $\begin{array}{c}\text { Trade } \\
\text { Balance } \\
(\mathrm{TB}) \\
=(\mathrm{X}-\mathrm{M}) \\
(\mathrm{m} . \mathrm{US} \$)\end{array}$ \\
\hline $2009-10$ & 304.62 & 3202.1 & 3506.72 & 8.69 & -2897.48 \\
\hline $2010-11$ & 512.5 & 4560.01 & 5072.51 & 10.10 & -4047.51 \\
\hline $2011-12$ & 490.42 & 4758.89 & 5249.31 & 9.34 & -4268.47 \\
\hline $2012-13$ & 563.96 & 4776.9 & 5340.86 & 10.56 & -4212.94 \\
\hline 2013-14 & 456.63 & 6035.51 & 6492.14 & 7.03 & -5578.88 \\
\hline $2014-15$ & 527.16 & 5828.1 & 6355.26 & 8.29 & -5300.94 \\
\hline $2015-16$ & 689.62 & 5452.9 & 6142.52 & 11.23 & -4763.28 \\
\hline $\begin{array}{l}\text { Growth } \\
\text { Rate }(\%) \text { : } \\
2009-10 \text { to } \\
2015-16\end{array}$ & 226.39 & $\begin{array}{c}170.29 \\
\text { (182.01 at } \\
\text { peak year) }\end{array}$ & 175.16 & NA & 164.39 \\
\hline $\begin{array}{l}\text { Annual } \\
\text { average } \\
\text { Growth } \\
\text { Rate }(\%)\end{array}$ & 37.73 & $\begin{array}{c}28.38 \\
(30.33 \text { at } \\
\text { peak year })\end{array}$ & 29.19 & NA & 27.40 \\
\hline
\end{tabular}

Sources: DCCI (2016)-Dhaka Chamber of Commerce and Industries, Dhaka, Bangladesh and author calculations 
As reported in other studies related to informal trade (Bhardwaj 2014), Bangladesh has additional large trade deficit of similar magnitude (estimated around additional USD 4000 million) in its informal trade with India. As such, the combined formal and informal trade deficit is really large and clearly unsustainable from Bangladesh perspective. As such, even a larger annual average growth rate of exports to India (37.73\%) compared to annual average import growth $(28.38 \%)$ as reported in the last row of Table 4 but from a smaller export base for Bangladesh and with a very small share of Bangladesh exports to India to its total trade with that country could not have any significant deficit reduction impact. The asymmetrical trade relationship against Bangladesh (in favor of India) resulting in a big and persistent trade deficit for Bangladesh is clearly not sustainable on a long-run basis and hence is of major concerns among for academics, policy makers, political leaders and people at large in Bangladesh. Given the above, it seems clear that it may take many years to reduce the deficits to more sustainable level.

\section{Bangladesh-India Trade: Disaggregated Analysis by Major Product Categories}

To gain further insights into the asymmetric trade situation of Bangladesh visà-vis India, this section focuses on disaggregated analysis of current trade and trade patterns by major commodity or product categories, particularly the top nine/ten products traded between the two countries. The respective market share of top export products from Bangladesh to India as \% of total Bangladesh exports to India is calculated using equation (12) while that of top import product share was calculated using equation (13) given earlier.

Table 5. Bangladesh's Top 9 Export Goods to India and Share (\%):2015-16

\begin{tabular}{|l|c|c|}
\hline Products & Exports (million US\$) & \% of Total Exports \\
\hline Jute Goods & 164.06 & 23.79 \\
\hline Woven Garments & 102.17 & 14.82 \\
\hline Raw Jute & 96.69 & 14.02 \\
\hline Agricultural Products & 82.00 & 11.89 \\
\hline Knitwear & 34.25 & 4.97 \\
\hline Leather \& Leather Products & 19.88 & 2.88 \\
\hline Home Textile & 14.66 & 2.13 \\
\hline Footwear & 12.48 & 1.81 \\
\hline Bicycle & 7.39 & 1.07 \\
\hline Total Top 9 Export Goods & $\mathbf{5 4 0 . 2 5}$ & $\mathbf{7 8 . 3 4}$ \\
\hline Others & $\mathbf{1 4 9 . 3 7}$ & 21.66 \\
\hline Total Exports & $\mathbf{6 8 9 . 6 2}$ & $\mathbf{1 0 0 . 0 1}$ \\
\hline
\end{tabular}

Sources: DCCI (2016)-Dhaka Chamber of Commerce \& Industries, Dhaka, Bangladesh and author calculations.

Table 5 shows Bangladesh's top nine export products to India along with the estimated percentage share of each of the ten products as \% of total exports to India for 2015-16, the most recent year for which data could be obtained. This table shows that manufactured Jute goods is the largest export earner $(23.79 \%)$ 
followed by woven garments $(14.82 \%)$ and raw jute $(14.02 \%)$ respectively in the second and third position. Bangladesh also exports some agricultural products $(11.89 \%)$ and some other items such as knitwear, leather and leather products and home textiles. The top 9 products constitute about $78.34 \%$ of Bangladesh total exports of 689.62 million USD with the remaining other products capturing about $21.66 \%$ of total exports to India.

In contrast, Table 6 shows Bangladesh's top ten import products from India along with the estimated share of each of the ten products as \% of total imports from India for 2015-16, the most recent year for which data could be obtained. This table shows that cotton (all types) constitute the largest import item with a share of $26.92 \%$ followed by vehicles $(9.36 \%)$, nuclear related materials $(7.71 \%)$, and cereals $(5.31 \%)$ respectively in the second, third and fourth position. The top 10 products constitute about $70.44 \%$ of Bangladesh total imports of 5452.90 million USD with the remaining other products capturing about $29.56 \%$ of total imports from India.

Table 6. Bangladesh's Top 10 Import Goods from India and Share (\%): 2015-16

\begin{tabular}{|l|c|c|}
\hline Products & $\begin{array}{c}\text { Import s } \\
\text { (million } \\
\text { US\$) }\end{array}$ & $\begin{array}{c}\% \text { of } \\
\text { Total } \\
\text { Imports }\end{array}$ \\
\hline Cotton (all types), cotton yarn / thread and cotton fabrics & 1468.01 & 26.92 \\
\hline $\begin{array}{l}\text { Vehicles other than railway or tramway rolling- stock and } \\
\text { parts and accessories }\end{array}$ & 510.31 & 9.36 \\
\hline $\begin{array}{l}\text { Nuclear reactor, boilers, machinery and mechanical } \\
\text { appliances, parts thereof }\end{array}$ & 420.31 & 7.71 \\
\hline Cereals & 289.12 & 5.31 \\
\hline Edible vegetables and certain roots and tubers & 260.81 & 4.78 \\
\hline Iron and steel & 236.41 & 4.34 \\
\hline Organic chemicals & 174.92 & 3.21 \\
\hline $\begin{array}{l}\text { Electrical machinery and equipment and parts thereof, sound } \\
\text { recorders and reproducers, television image and sound } \\
\text { recorders and reproducers and parts and accessories of such } \\
\text { articles }\end{array}$ & & \\
\hline Plastics and articles thereof & 171.32 & 3.14 \\
\hline $\begin{array}{l}\text { Tanning or dyeing extracts, tannins and their derivatives, } \\
\text { dyes, pigments and other coloring matter, paints and } \\
\text { varnishes, putty and other mastics, inks }\end{array}$ & 158.01 & 2.91 \\
\hline Total Top Ten Import Goods & 149.91 & 2.76 \\
\hline Others & $\mathbf{3 8 4 1 . 0 2}$ & $\mathbf{7 0 . 4 4}$ \\
\hline Total Imports & 1611.88 & 29.56 \\
\hline Soures: DCCI & $\mathbf{5 4 5 2 . 9 0}$ & $\mathbf{1 0 0 . 0 1}$ \\
\hline
\end{tabular}

Sources: DCCI (2016)-Dhaka Chamber of Commerce and Industries and author calculations.

Table 7 provides disaggregated data of exports and imports by 18 HS 2-digit major product categories. Estimated product specific total trade (Ti) for these products are reported in col. 6 for each product category using equation (14) and trade balance (TBi) for each product category is reported in col. 5 using equation (15). Column 5 shows that Bangladesh had trade surplus (+) for 8 out of 18 product categories with trade deficit in the remaining 10 categories. 
Table 7. Trade, Trade Balance and RCA by HS 2-digit Major Product Categories, 2015-16

\begin{tabular}{|c|c|c|c|c|c|c|c|}
\hline HS & Product & Exports (Xi) & Imports (Mi) & $\mathrm{TBi}=(\mathrm{Xi}-\mathrm{Mi})$ & $(\mathrm{Xi}+\mathrm{Mi})$ & $\begin{array}{c}\text { RCAi: } \\
\text { (Xi-Mi) } \\
/(\mathrm{Xi}+\mathrm{Mi})\end{array}$ & $\begin{array}{c}\text { Adv (+) } \\
\text { DisAdv (-) } \\
\text { Neutral (0) }\end{array}$ \\
\hline Code & Category & (US\$) & US\$) & (US\$) & (US\$) & Ratio & Comment \\
\hline 03 & Seafood & $636,458,207$ & 0 & $636,458,207$ & $636,458,207$ & +1.00 & Adv \\
\hline 10 & Cereals & 0 & $1,837,969,824$ & $-1,837,969,824$ & $1,837,969,824$ & -1.00 & DisAdv \\
\hline 15 & Fats and Oils & 0 & $3,551,898,136$ & $-3,551,898,136$ & $3,551,898,136$ & -1.00 & DisAdv \\
\hline 27 & $\begin{array}{c}\text { Oil and Mineral } \\
\text { Fuels }\end{array}$ & $280,088,410$ & $3,126,389,886$ & $-2,846,301,476$ & $3,406,478,296$ & -0.84 & DisAdv \\
\hline 31 & Fertilizers & 0 & $1,983,289,320$ & $-1,983,289,320$ & $1,983,289,320$ & -1.00 & DisAdv \\
\hline 39 & Plastics & 0 & $1,302,968,206$ & $-1,302,968,206$ & $1,302,968,206$ & -1.00 & DisAdv \\
\hline 41 & $\begin{array}{l}\text { Hides and } \\
\text { Leather }\end{array}$ & $323,758,964$ & 0 & $323,758,964$ & $323,758,964$ & +1.00 & Adv \\
\hline 52 & Cotton & $123,674,252$ & $6,692,856,498$ & $-6,569,182,246$ & $6,816,530,750$ & -0.96 & DisAdv \\
\hline 53 & Natural Fibers & $822,979,223$ & 0 & $822,979,223$ & $822,979,223$ & +1.00 & Adv \\
\hline 58 & $\begin{array}{l}\text { Lace and } \\
\text { Tapestries }\end{array}$ & $107,017,617$ & 0 & $107,017,617$ & $107,017,617$ & +1.00 & Adv \\
\hline 61 & Apparel ; Knit & $9,936,304,901$ & 0 & $9,936,304,901$ & $9,936,304,901$ & +1.00 & Adv \\
\hline 62 & $\begin{array}{c}\text { Apparel ; Non- } \\
\text { knit } \\
\end{array}$ & $9,225,733,521$ & 0 & $9,225,733,521$ & $9,225,733,521$ & +1.00 & Adv \\
\hline 63 & Textile Articles & $1,073,491,458$ & 0 & $1,073,491,458$ & $1,073,491,458$ & +1.00 & Adv \\
\hline 64 & Footwear & $345,642,613$ & 0 & $345,642,613$ & $345,642,613$ & +1.00 & Adv \\
\hline 72 & Iron and Steel & 0 & $1,800,284,144$ & $-1,800,284,144$ & $1,800,284,144$ & -1.00 & DisAdv \\
\hline 84 & $\begin{array}{c}\text { Industrial } \\
\text { Machinery }\end{array}$ & 0 & $3,894,441,294$ & $-3,894,441,294$ & $3,894,441,294$ & -1.00 & DisAdv \\
\hline 85 & $\begin{array}{c}\text { Electrical } \\
\text { Machinery }\end{array}$ & 0 & $2,773,027,524$ & $-2,773,027,524$ & $2,773,027,524$ & -1.00 & DisAdv \\
\hline 89 & Ships and Boats & 0 & $1,317,728,008$ & $-1,317,728,008$ & $1,317,728,008$ & -1.00 & DisAdv \\
\hline
\end{tabular}


Further, as estimates in Table 7 shows, we have calculated the Balassa type (Balassa 1965; Islam, Nuwal and Nguyen 2011; and Islam and Dong 2011) Revealed Comparative Advantage RCAi index using equation (16) and the steps in calculation are shown and reported in the last four columns of this table. Mirroring the trade deficit result, there is positive RCAi indicating revealed comparative advantage for 8 products ( $44 \%$ of the listed products) and negative RCAi (revealed comparative disadvantage) for the remaining 10 product categories (56\% of the listed products). As such, Bangladesh seems to have revealed comparative advantage in products such as seafood, hides and leather, natural fiber, lace and tapestries, knit and non-knit apparel, textile articles, and footwear. The list of products with comparative disadvantage are found in cereals, fats and oils, oils and mineral fuels, fertilizers, plastics, cotton, iron and steel, industrial and electrical machineries and ships and boats.

\section{Conclusions and Further Discussions}

The empirical findings of the paper can be summarized as follows: (1) Due to its advantage over resource endowments better resource varieties, higher education and skill level of labor force, better technology, better institutions and infrastructure, bigger internal market with greater size of the economy, India is found to dominate Bangladesh in the context of global trade and global markets. (2) However, at the same time, given some similarity in resource endowments with both countries having abundant low-wage labor supply, both countries seem to have comparative advantage in similar labor-intensive products, both countries seems to have greater degree of trade competitiveness than trade complementarities, resulting in both countries competing in similar products in global markets (Basu and Datta 2007a). That creates a problem for a smaller country like Bangladesh to compete against India which has a more diversified basket of export goods. (3) India is also found to dominate strongly in terms of bilateral trade at the aggregate level with stronger trade position vis-à-vis Bangladesh, resulting in a large and persistent trade deficit for Bangladesh against India.

In addition, (5) In terms of disaggregated data, we estimated and Analyzed the comparative advantage based RCA inter-industry trade for top eighteen (18) HS 2-digit product categories. In the estimated RCAi, (Revealed Comparative Advantage in industry i) methodology, India is found to have a much stronger comparative advantage in a larger number of major product categories than Bangladesh such that among the top eighteen (18) HS 2-digit product categories examined, India had positive RCA for 10 products (56\%) and Bangladesh with 8 products $(44 \%)$ of those product categories. This result is not a surprise give the size of the Indian economy and its much better resource endowments vis-à-vis Bangladesh.

Furthermore, (6) Bangladesh trade with India seems to be dominated by imports from India to the tune of about $89 \%$ of all trade with Bangladesh exports constituting only about $11 \%$ of all trade between them. (7) In spite of the fact that the annual average export growth seem to be slightly higher than its annual 
average import growth, a hopeful sign for Bangladesh to improve its trade deficit position in the future, however, given its smaller export base and smaller export share relative to import share in total trade, the deficit seems to be stubborn and persistent for Bangladesh. (8) Added to this large and persistent deficit in formal trade is the additional trade deficit of similar magnitude from informal trade between the two countries that makes the situation much worse from Bangladesh perspective.

Thus the deficit position is not only larger in terms of combined formal and informal trade, but also the deficits are persistent over time and these should a major concern for political leaders and policy makers in both countries. To achieve trade balance improvement faster, it seems clear that more positive policy action would be needed on the part of both countries to improve the trade imbalance of Bangladesh with India to make it sustainable in the long-run. Some policy actions may be that India, being the larger and stronger of the two countries, could take various policy actions to improve market access of Bangladeshi products into the larger Indian market. At the same time, Bangladesh needs to expand its export product lines so as to take advantage of such improved market access. These actions are expected to reduce the deficit towards a more sustainable level over the long-run, if not immediately.

\section{References}

Ahmed I (2006) Bangladesh-India Relations: The context of SAARC and the Emerging Global Scenario. Conference paper, Asian Affairs, April-June, 28(2): 46-62.

Akhtar HA, Salim R (1999) The Political Economy of Bangladesh's Large and Growing Trade Deficits with India. The Pakistan Development Review 38(1): 25-68.

Alam KA, Uddin MGS, Alam MM, Malakar B (2009) Trade Patterns of Bangladesh with India and China: An Empirical Evidence of the PPP Theory. Journal of Regional Economic Studies (2): 26-34.

Bakht Z (1994) BIDS study on Illegal International Trade in Bangladesh, 1990: An Update. Bangladesh Institute of Development Studies. Dhaka, Bangladesh, (mimeographed).

Bammi YM (2010) India Bangladesh Relations: The Way Ahead, Vij Books India Pvt. Ltd., India, 51-54.

Basu S, Datta D (2007a February) India-Bangladesh Trade Deficits and Misaligned Bilateral Exchange Rate: Can Bangladesh Draw Lessons from Indonesia? Journal of the Asia Pacific Economy 12(1): 76-102.

Basu S, Datta D (2007b January-June) India-Bangladesh Trade Relations: Problem of Bilateral Deficit. Indian Economic Review, New Series 42(1): 111-129.

Basher MdA (2013 April) Indo-Bangla Trade: Composition, Trends and Way Forward. Revised Draft paper, the Commonwealth Secretariat, 4-21.

Balassa B (1965 May) Trade Liberalization and Revealed Comparative Advantage. The Manchester School of Economic and Social Studies 33: 99-123.

Bhardwaj S (2014 June) An Agenda for the New Government: Policy Options for India in Bangladesh. Institute of Peace and Conflict Studies, IPCS issue brief no. 251. Retrieved from https://bit.ly/2pXfxnz. 
Bhuyan AR (2006) Bangladesh-India Trade Relations- Prospects of a Bilateral FTA. Thoughts on Economics 18(02): 8-34.

Chaudhari SK (1995) Cross Border Trade between India and Bangladesh. National Council of Applied Economic research (NCAER), Working Paper 58, New Delhi, India.

De P, Bhattacharyay BN (2007) Prospects of India-Bangladesh Economic Cooperation: Implications for South Asian Regional Cooperation. Discussion Paper No. 78, Asian development Bank, September, 1-36.

De P, Raihan S, Kathuria S (2012 August) Unlocking Bangladesh-India Trade-Emerging Potential and the Way Forward. Policy Research Working Paper, No 6155, The World Bank -South Asia Region Economic Policy and Poverty Sector, 1-33.

DCCI (2016) Data on Bangladesh and India Trade. Dhaka Chamber of Commerce and Industries. Retrieved from https://bit.ly/2PAeOnK.

Dutta P (2010) India-Bangladesh Relations issues, problems and recent developments. Institute of Peace and Conflict Studies, IPCS Special report, September, 97: 1-10.

Globaledge (2018) Globaledge database. Michigan State University. Retrieved from https://bit.ly/2ClYBPa.

Grubel HG, Lloyd PJ (1975) Intra-Industry Trade: The Theory and Measurement of International Trade in Differentiated Products. New York: John Wiley and Sons.

IBCCI (2016) India Bangladesh Trade. India-Bangladesh Chamber of Commerce and Industry. Retrieved from https://bit.ly/2yGSgdu.

Islam MM (2011 April-June) Trade cooperation between Bangladesh and India with Special Reference to the North-East India. Dialogue 12 (4). Retrieved from https://bit.ly/2J43BJn.

Islam RMG, Khan MT, Ishak A (2013) Bilateral and International Trade of Bangladesh and India: Effect of Falling Exchange Rate of Indian Rupee. European Journal of Business and Management 5(27): 33-39.

Islam A, Nuwal T, Nguyen C (2011) India's Economic Reforms and U.S. India Bilateral Trade Flows. International Journal of Global Management 1(2): 55-73.

Islam A, Dong H (2011 March) A Brief Overview of China's Global Trade performance. Southwest Review of International Business Research 22(1): 1-7.

Khan RM, Islam T, Ashiqun N, Paul TK (2010 July) Bangladesh's Export Opportunities in the Indian Market: Addressing Barriers and Strategies for future. Occasional Paper 90, Centre for Policy Dialogue (CPD) 1-26.

Mukherjee D (2015) India-Bangladesh: new trade links. Retrieved from https://bit.ly/ 2EFUT5V.

Pohit S, Taneja N (2000) India's Informal Trade with Bangladesh and Nepal: A Qualitative Assessment. Indian Council for research on International Economic Relations, New Delhi, India. Retrieved from https://bit.ly/2QZRVKO.

Pohit S, Taneja N (2003) India's Informal Trade with Bangladesh: A Qualitative Assessment. World Economy. Blackwell Publishing Ltd. 26(8): 1187-1214.

Pursell G (2007 June) Smuggling and Economic Welfare Consequences of an FTA: A Case Study of India-Bangladesh Trade in Sugar. Australia South Asia Research Center, Australian National University. Retrieved from https://bit.ly/2CoUf9W.

Pursell G, Sattar Z (2006) India-Bangladesh Bilateral Trade and Potential Free Trade Agreement, 1-96. Bangladesh Development Series Paper No: 13. The World Bank, World Bank Office Dhaka Bangladesh.

Rahman MM (2005 June) Bangladesh-India Bilateral Trade: Causes of Imbalance and Measures for Improvement. Research paper. University of Sydney, NSW, Australia. Retrieved from https://bit.ly/2Ow8sJt. 
Rather ZA, Gupta D (2014) India-Bangladesh Bilateral Trade: Problems and Prospects. International Affairs and Global Strategy 22(1): 42-48.

Razzaque MA, Basnett Y (2014) Regional Integration in South Asia: Trends, Challenges and Prospects, 1-518. London: Commonwealth. Retrieved from https://bit.ly/2PC $31 \mathrm{VT}$

Taneja N (2001 March) Informal Trade in SAARC Region. Economic \& Political Weekly 36(11). Retrieved from https://bit.ly/2pXJGDt.

World Bank (2006) India-Bangladesh Bilateral Trade and Potential for free Trade Agreement, 1-72. Bangladesh Development Series, Paper No. 13, The World Bank Office, Dhaka, Bangladesh.

World Bank (2015) Informal and illegal trade: dimensions, trends, composition, and the role of domestic indirect taxes. Chapter 8 , Retrieved from https://bit.ly/2CoTwFS.

World Bank (2018) World Development Indicators database. Washington DC, USA: World Bank. Retrieved from https://bit.ly/1eYCES4.

WTO (2018) Country Trade Profile, the World Trade Organization data base. Retrieved from https://bit.ly/1lH96ij. 